\title{
PENURUNAN BAU LIMBAH CAIR INDUSTRI TEPUNG IKAN MENGGUNAKAN CUKA, AERASI, OZONE DENGAN INDIKATOR LALAT
}

\author{
REDUCTION ODOR of THE FISHMEAL INDUSTRY WATER WASTE by \\ VINEGAR, AERATION, OZONE WITH FLIES INDICATOR
}

\author{
Hermain Teguh Prayitno \\ Kantor Penelitian dan Pengembangan Kabupaten Pati \\ Email : hermainteguh70@Gmail.com
}

\begin{abstract}
The odor of fishmeal industry in Pati regency can be smelled during the trip from Pati to Juwana. The odor comes from the chimney and industrial environment, especially on the Waste Water Treatment Plant (WWTP). The odor is likely to come from the rotten fish which are not preserved well by fishermen and traders. The rotten odor comes from crushed-belly fish mix with floorcleaning waste in the WWTP. Furthermore, the odor is lift to the air through aeration. The research aimed to analyze the contribution of aeration, ozonation, and acid treatment to odor production with the fly existence as the indicator. The original odor was neutralized during the first treatment through explorative experiment. The parameters were: vinegar addition, aeration, and ozonation. The indicators were: the type and number of flies. The analysis resulted thatthe mixture of water waste and vinegar in the aeration and ozonation created the odor liked by house flies, but it was not economical. The correlation of the aeration and the appearance of green flies was significantly proved with the value of Pearson Correlation was 0,579 ( $p<0,05)$. It means the process of ozonation allowed the reduction of water waste odor during the pre-treatment process.
\end{abstract}

Keyword : Bluebottle, Aeration, Ozonisasi, wastewater

\begin{abstract}
ABSTRAK
Permasalahan bau di industri tepung ikan di Kabupaten Pati dapat dirasakan jika kita menempuh perjalanan Pati ke Juwana. Bau berasal dari cerobong asap dan lingkungan industri, terutama pada Instalasi Pengolahan Air Limbah. Perkiraan bau berasal dari bau bawaan ikan busuk yang tidak dirawat ( pengawetan ) oleh nelayan dan pedagang. Bau bawaan berasal dari ikan yang pecah perut masuk ke IPAL bersamaan dengan pembersihan lantai, kemudian terangkat ke udara melalui aerasi. Tujuan penelitian adalah mengetahui pengaruh aerasi, ozonisasi, dan dalam kondisi asam terhadap produksi bau dengan indikator keberadaan lalat.Upaya menetralkan bau bawaan pada pengolahan awal ini dilakukan dengan metode eksploratif eksperimental, variabel cuka, aerasi, dan ozonisasi. Indikator pengamatan adanya jenis dan jumlah lalat. Analisis menghasilkan bahwa campuran limbah cair dan cuka di aerasi dan di ozonisasi mengeluarkan bau segar yang disukai lalat rumah, akan tetapi tidak ekonomis. Lalat hijau menyukai bau busuk hasil dari aerasi dengan korelasi 0,579 ke tiga botol dan signifikan 0,048. Artinya pengolahan menggunakan ozon memungkinkan untuk menurunkan bau pada limbah cair pada pengolahan awal IPAL industri ikan.
\end{abstract}

Kata Kunci : Lalat hijau, Aerasi, Ozonisasi, limbah cair 


\section{PENDAHULUAN}

Kabupaten Pati memiliki potensi hasil perikanan laut yang sangat besar. Mulai nelayan kecil hingga nelayan besar berada di PPI Bajomulyo. Produksi ikan yang berlimpah menyisakan, dan membawa ikan non konsumtif (ikan rucah). Ikan tersebut tanpa mengalami pengolahan yang selayaknya (pencucian dan pendinginan) sehingga tercium bau busuk ikan saat diturunkan dan menetap disekitar TPI maupun PPI Juwana. Hal serupa juga terjadi di TPI Tayu, Banyu Towo, dan sering juga dari TPI Rembang.

Ikan busuk diangkut menggunakan kendaraan truk menuju industri penepungan dengan kondisi basah dan menetes sepanjang jalan, sehingga pengendara di belakang truk kebanyakan tidak merasa nyaman. Hasil pengamatan menunjukkan bahwa terdapat ceceran cairan ikan di jalan dan dalam ruang pembongkaran ikan pada kedua industri tepung ikan di Kabupaten Pati.

Ceceran ikan di jalan menuju ruang bongkar, penyiraman ikan di ruang bongkar ikan, dan aerasi pada bak pengolahan limbah cair berpotensi mengeluarkan bau ikan bawaan ke udara dan mencemari bau lingkungan industri, serta masyarakat pengguna jalan Pati Juwana.Pengolahan limbah pada kedua industri tersebut tergolong sudah lengkap, bahkan dioperasikan dengan baik, akan tetapi sistem yang diterapkan belum mengakomodasi bau limbah bawaan, maka penelitan penurunan bau bawaan limbah cair indutri tepung ikan ini perlu dilakukan

Berdasarkan latar belakang tersebut maka tujuan penelitian adalah mengetahui pengaruh aerasi, ozonisasi, dan dalam kondisi asam terhadap produksi bau dengan indikator keberadaan lalat.

\section{TINJAUAN PUSTAKA}

\section{PercobaanOzon}

Konsentrasi sisa ozon dengan perlakuan $\mathrm{pH}$ basa lebih kecil nilainya dibandingkan dengan $\mathrm{pH}$ netral dan Asam (Sari, 2013). Hal ini dapat digunakan referensi penggunaan asam untuk pereaksi ozon untuk menetralisir limbah cair.

Penambahan kapur dimaksudkan untuk menambah jumlah ion $\mathrm{OH}$ sedangkan parameter waktu ozonisasi dimaksudkan untuk menyempurnakan oksidasi senyawa-senyawa organik dalam limbah dan pembentukan flokflok. Dari penelitian yang dilakukan diperoleh Semakin besar waktu ozonisasi dikenakan dalam limbah maka semakin turun kadar BOD, COD, TSS dan fosfat, waktu ozonisasi 20 menit, (Isyuniarto, 2007). Variabel waktu pemberian ozon perlu diperhatikan dengan keberadaan $\mathrm{pH}$ untuk membentuk flok-flok yang berpotensi mengendap, dan mampu membantu pengolahan berikutnya.

Salah satu contoh kajian pengaruh penggunaan oksidan ozon untuk menurunkan BOD, COD dan TSS dalam limbah cair industri adalah pada industri limbah udang. Volume limbah untuk setiap perlakuan sebanyak $500 \mathrm{ml}$, diozonisasi selama 10 menit, dengan variasi $\mathrm{pH}$ limbah $7,8,9,10$ dan 11 dengan cara pemberian kapur tohor. Dengan $\mathrm{pH}$ yang optimal kemudian digunakan untuk perlakuan berikutnya, yaitu variasi waktu pemberian ozon : 0 , 5, 10, 15, 20, dan 25 menit. Dari percobaan diperoleh data bahwa kondisi yang optimal adalah pada $\mathrm{pH}=9$ dan waktu ozonisasi 20 menit. Pada kondisi ini diperoleh kadar ketiga pencemar 
adalah $\mathrm{BOD}=41 \mathrm{mg} / \mathrm{l}, \mathrm{COD}=54 \mathrm{mg} / \mathrm{l}$, dan TSS = $25 \mathrm{mg} /$, (Isyuniarto, 2006).

Dalam penelitian Enjarlis (2006), perbandingkan penyisihan karbofuran dalam air dengan proses ozonasi nonkatalitik dan katalitik menggunakan katalis karbon aktif. Ragam percobaan yaitu pH (2, 7, dan 9) pada suhu kamar selama 60 menit. Analisis konsentrasi karbofuran menggunakan kromatografi gas dan konsentrasi zat organik sebagai Chemical Oxigen Deman (COD) secara titrasi pada satiap10 menit selama 60 menit. Hasil percobaan memperlihatkan proses ozonasi katalitik dan non-katalitik terbaik pada kondisi basa ( $\mathrm{pH}$ 9) dengan penyisihan karbofuran $100 \%$ dan COD turun dari 134 ppm menjadi 38 ppm untuk ozonasi katalitik, sedangkan pada ozonasi non-katalitik penyisihan karbofuran 46,4\% dan COD turun menjadi 70 ppm. Perubahan suhu dan $\mathrm{pH}$ selama proses baik ozonasi katalitik maupun non-katalitik tidak menunjukkan perubahan yang berarti.

\section{Indikator Lalat}

PenelitianMayasari

(2008)

menyebutkan bahwa lama waktu kematian atau post mortem interval tidak dapat ditentukan dengan absolut oleh ahli forensik, melainkan hanya perkiraan yang mendekati kebenarannya. Lama waktu kematian dapat ditentukan dengan mengidentifikasi perubahan-perubahan yang terjadi pada mayat, baik perubahan internal maupun eksternal. Pemeriksaan yang sering dilakukan yaitu pemeriksaan tanda pasti kematian berupa lebam mayat, kaku mayat, penurunan suhu tubuh, serta pembusukan.Tetapi pada penemuan mayat yang sudah lama mengalami kematian dan telah membusuk, tanda-tanda tersebut menjadi sulit diidentifikasi. Salah satu alternatif yang dapat digunakan pada pemeriksaan mayat yang telah membusuk yaitu jika terdapat organisme yang berkembang biak pada mayat tersebut. Lalat merupakan salah satu serangga yang tertarik pada bau busuk mayat dan beberapa jenis lalat menggunakan mayat yang membusuk sebagai media perkembangbiakan.

Lalat sangat terpengaruh oleh baubauan, dari bau lemah maupun bau yang sangat menyengat. Kehadiran lalat tergantung dengan jenis bau yang ditimbulkan, dari penelitian sebelumnya antara lalat rumah, lalat daging, dan lalat hijau terpengaruh oleh kuat dan jenis bauan. Penelitian terdahulu meneliti larva lalat, karena biasanya mayat (korban) ditemukan setelah beberapa hari, maka jenis dan jumlah larva lalat yang lebih penting. Lalat dapat terpengaruh oleh bau-bauan yang menyengat apalagi bau busuk, dan dalam penelitian ini adalah potensi produksi bau menyengat mampu mendatangkan lalat, maka pengamatan kedatangan lalat ( potensi lalat rumah dan lalat hijau ) untuk di catat dan dianalisis.

\section{METODE PENELITIAN}

Penelitian ini bersifat eksploratif dengan jenis eksperimental. Data diambil melalui observasi di lapangan, dan percobaan pengolahan skala laboratorium di Desa Jatimulyo Wedarijaksa Kabupaten Pati, mulai bulan mei sampai dengan bulan Agustus 2016. Penelitian yang mencari hal-hal baru dan belum diteliti sebelumnya menggunakan sifat eksplorasi, akan tetapi perbandingan hasil percobaan harus dilakukan dengan menggunakan blanko dan atau pereaksi lain yaitu pengasaman.

Metode pengumpulan data yaitu data informasi umum dan teknis yang berhubungan dengan limbah cair tepung ikan diambil melalui observasi di lapangan (dua industri tepung ikan) dan di lokasi perolehan ikan (TPI dan PPI). 
Sumber bahan baku percobaan diperoleh dari salah satu industri tepung ikan yaitu

limbah cair yang berada di lokasi influent IPAL.

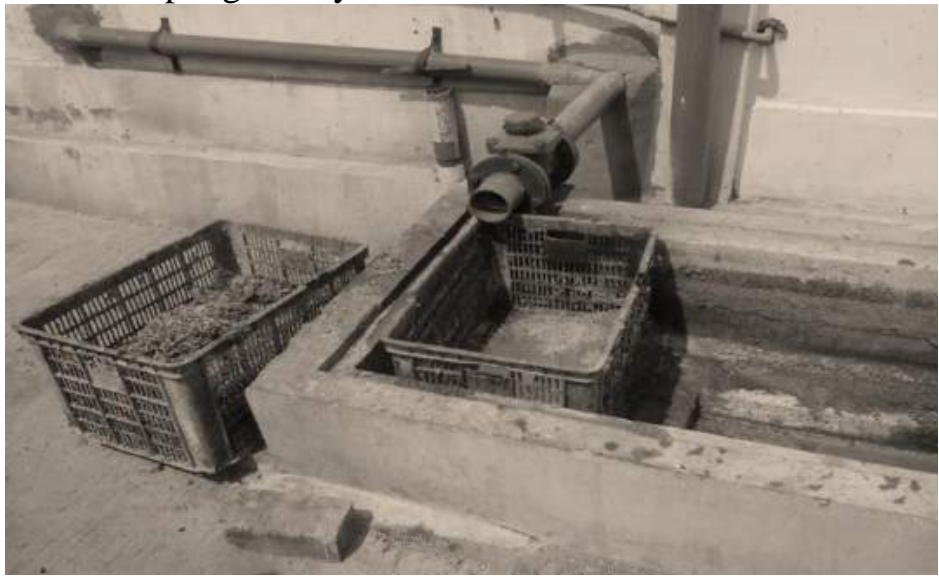

Gambar 1.

Lokasi Pengambilan Sampel Limbah Cair

Sumber : Pengamatan Lapangan, 2016

Langkah pelaksanaan percobaan yaitu(1) sebelum dilakukan percobaan, air limbah dilakukan pengecekan kualitas $\mathrm{pH}$, TDS, dan temperatur. (2) Percobaan ini dilakukan 2 tahap yaitu tahap pertama, pengolahan dengan cara sifat keasaman limbah cair dengan cara menambahkan ke tiga botol dengan variasi cuka 2, 4, $6 \mathrm{~mL}$ setiap botol dengan volume limbah 1 liter. (3) ketiga botol direaksi dengan aerasi dan 3 botol berikutnya dengan ozonisasi, selama 120 menit.(4) Tahap kedua dilakukan hari kedua dimana limbah cair sudah sangat rusak (bau), sehingga mampu menarik lalat untuk digunakan sebagai indikator pada reaksi aerasi atau ozonisasi. Variasi waktu proses aerasi dan ozonisasi dilakukan sebagai berikut 3 botol di aerasi dalam waktu 30, 45, dan 60 menit. Dan jeda waktu 15 menit antar botol, sehingga terproduksi bau baru setiap 15 menit. Demikian juga dengan ozonisasi. (5) Perolehan data dilakukan dengan carapencatatan kehadiran lalat setiap waktu di masa waktu percobaan, baik percobaan pertama maupun kedua. (6)
Setelah tahap kedua selesai kemudian dilakukan pengecekan ulang hasil pengolahan dengan kualitas TDS, $\mathrm{pH}$, dan temperatur.

Analisis data menggunakan aplikasi SPSS dan data foto kecerahan dengan menggunakan program picasa 3 . Kemudian disimpulkan sampel percobaan yang manakah yang ekonomis dan mampu menurunkan bau.

\section{HASIL DAN PEMBAHASAN}

\section{Percobaan Tahap Pertama}

Limbah cair pada salah satu industri tepung ikan di Kabupaten Pati diambil 1 derigen berisi 40 liter pada hari sabtu 11 Juni 2016 pukul 12.00. Komposisi pengecekan di lapangan menjelaskan air tanah dengan Total Dissolved Solid (TDS) $2,750 \mathrm{mg} / \mathrm{L}$ dan pH 7,7. Limbah inlet IPAL TDS 4,150 $\mathrm{mg} / \mathrm{L}$ dan $\mathrm{pH}$ 6,9. Limbah proses yang berada di IPAL TDS $2,230 \mathrm{mg} / \mathrm{L}$ dan $\mathrm{pH}$ 8,6 . Serta di bak pengendapan IPAL TDS $2,320 \mathrm{mg} / \mathrm{L}$ dan $\mathrm{pH} 8,3$. Bahan baku penelitian diambil pada bak inlet TDS (akumulasi) 4,440 mg/L dan $\mathrm{pH} \quad 6,8$. 
Pengolahan dilakukan di Desa Jatimulyo RT1/2 Kecamatan Wedarijaksa pada hari

Tabel 1.

Hasil Percobaan Tahap Pertama dengan Waktu 120 Menit

\begin{tabular}{ccccccccc}
\hline No & & \multicolumn{3}{c}{ Awal } & Proses & \multicolumn{3}{c}{ Akhir } \\
\hline Sampel & Cuka & TDS & pH & Temp. & 120 menit & TDS & pH & Temp. \\
\hline 0 & & 4.440 & 6,8 & 30 & aerasi & 4.280 & 8,3 & 34,0 \\
1 & $2 \mathrm{~mL}$ & 4.470 & 6,1 & 30 & ozonisasi & 4.260 & 8,2 & 33,9 \\
2 & $4 \mathrm{~mL}$ & 4.470 & 6,1 & 30 & ozonisasi & 4.280 & 8,1 & 34,3 \\
3 & $6 \mathrm{~mL}$ & 4.480 & 6,1 & 30 & ozonisasi & 4.310 & 8,3 & 32,8 \\
4 & $2 \mathrm{~mL}$ & 4.470 & 6,1 & 30 & aerasi & 4.270 & 8,0 & 33,9 \\
5 & $4 \mathrm{~mL}$ & 4.470 & 6,1 & 30 & aerasi & 4.280 & 8,2 & 34,6 \\
6 & $6 \mathrm{~mL}$ & 4.480 & 6,1 & 30 & aerasi & 4.280 & 8,3 & 34,1 \\
\hline
\end{tabular}

Sumber : Pengolaha Data, 2016

Tabel 1 hasil percobaan pertama dengan waktu 120 menit menjelaskan bahwa kadar kelarutan air dari sebelum diolah sampai hasil pengolahan ke 6 botol percobaan penurunannya tidak besar. Artinya penggunaan aerasi dan ozonisasi bukan sebagai alat pengolah minggu tanggal 12 Juni 2016 pukul 8.00 pagi. utama, hanya sebagai alat pembantu pengolahan. Penurunan $\mathrm{pH}$ awal dan $\mathrm{pH}$ akhir menunjukkan peningkatan yang besar, hal ini disebabkan masih banyaknya kandungan organik di dalam limbah sehingga proses pembusukan masih berjalan.

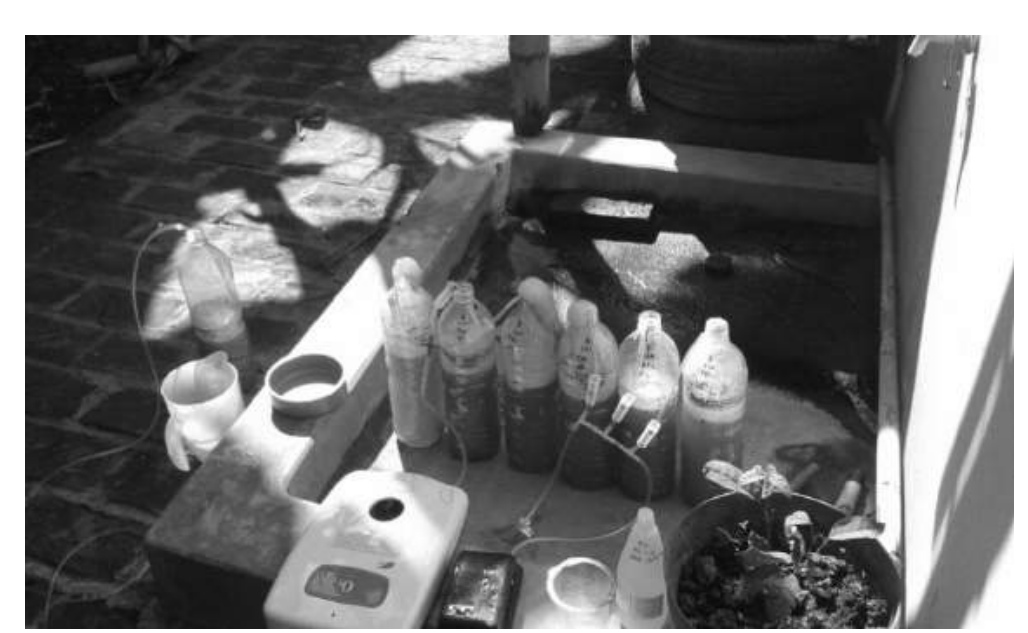

Gambar 2.

Foto Percobaan Tahap Pertama dengan Waktu 120 Menit Sumber : Pengamatan Lapangan, 2016

Gambar 2 merupakan sebagian dari gambar-gambar lainnya pada penelitian yang mewakili untuk ditampilkan, akan tetapi pada tahap awal 
bau segar, hal ini dibuktikan dengan kedatangannya lalat daging dan rumah. Kedatangan lalat terbanyak diurutkan sebagai berikut : botol nomor 2 didatangi lalat sebanyak 6 kali, botol nomor 3 didatangi lalat 4 kali, botol nomer 5 didatang lalat 4 kali, botol nomor 4 didatangi lalat 2 kali, botol nomor 6 didatangi lalat 1 kali. Campuran cuka 4 $\mathrm{mL}$ dan $6 \mathrm{~mL}$ ozonisasi dan cuka $4 \mathrm{~mL}$ aerasi tertinggi didatangi lalat rumah. Botol nomor 3 campuran $6 \mathrm{~mL}$ tercepat mengeluarkan buih disusul dengan botol nomor 1,4 , dan 6. Lalat tidak menyukai reaksi cuka yang menghasilkan buih dan hanya dikunjungi 2 kali pada botol nomor 4 dan sekali pada botol pada nomor 6 .

Hasil pengolahan menggunakan cuka, aerasi, dan ozon terlihat keruh hingga cerah mulai dari botol dan foto diolah menggunakan program foto picasa 3, dan mengatur isi cahaya, sorotan, bayangan, dan suhu warna. Hasil pengolahan foto disampaikan dalam Gambar 3.

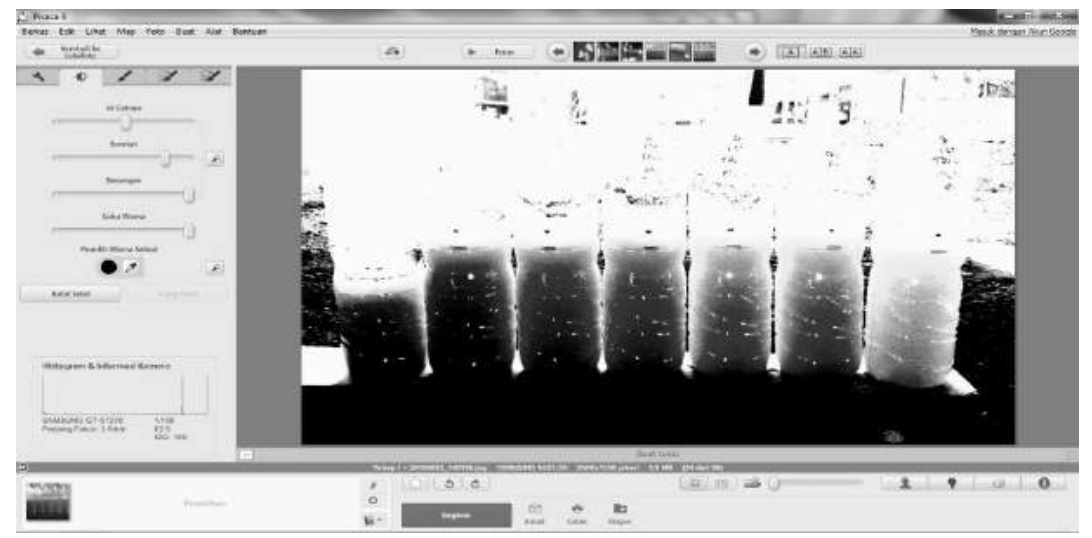

Gambar 3.

Foto Olahan Hasil Percobaan Tahap Pertama 120 menit

Sumber : Pengamatan Lapangan, 2016

Kecerahan foto dapat diurutkan mulai dari pertama botol nomor $5(4 \mathrm{~mL}$ cuka aerasi), kedua botol nomor $2(4 \mathrm{~mL}$ cuka ozonisasi), ketiga botol nomor 6 (6 $\mathrm{mL}$ cuka aerasi), keempat botol nomor 1 (2 mL cuka ozonisasi), kelima botol nomor 4 ( $2 \mathrm{~mL}$ cuka aerasi), dan keenam botol nomor 3 (6 mL ozoneisasi).

Penggunaan cuka mampu membantu pengolahan awal dan merubah bau menjadi segar, akan tetapi tidak direkomendasikan dikarenakan dengan menambahkan volume $4 \mathrm{~mL}$ setiap liter akan membutuhkan biaya operasional instalasi pengolahan air limbah yang sangat besar, maka penelitian dilanjutkan dengan optimalisasi ozon.

\section{Percobaan Tahap Kedua}

Pada percobaan tahap kedua dilakukan dengan pemakaian aerasi dan ozon. Hasil percobaan tahap kedua disajikan pada Tabel 2.

Penomeran 7/a berbeda dengan nomer botolnya yaitu nomer 7 , hal ini digunakan hanya untuk memudahkan penjelasan dari upaya pengolahan 2 tahap dan 2 waktu. Botol urut 1 sampai ke 6 pada pengolahan pertama, kemudian botol urut ke 7 sampai dengan 12 pengolahan ke dua. Artinya penambahan hurup a sampai dengan $f$ hanya untuk memudahkan pembacaan tahap ke dua, dan memudahkan dalam pengolahan data menggunakan SPSS. 
Tabel 2.

Hasil Percobaan Tahap Kedua dengan Waktu 30, 45, 60 Menit

\begin{tabular}{|c|c|c|c|c|c|c|}
\hline \multirow{2}{*}{$\begin{array}{c}\text { No } \\
\text { Sampel }\end{array}$} & \multicolumn{3}{|c|}{ Awal } & \multirow{2}{*}{ Proses } & \multicolumn{2}{|c|}{ Akhir } \\
\hline & Cuka & TDS & $\mathrm{pH}$ & & TDS & $\mathrm{pH}$ \\
\hline $7 / a$ & & 4510 & 6.9 & Ozonisasi 30mnt & 4510 & 7.5 \\
\hline $8 / b$ & & 4510 & 6.9 & Ozonisasi 45mnt & 4440 & 7.9 \\
\hline $9 / \mathrm{c}$ & & 4510 & 6.9 & Ozonisasi $60 \mathrm{mnt}$ & 4400 & 8.3 \\
\hline $10 / d$ & $2 \mathrm{~mL}$ & 4510 & 6.9 & Aerasi $30 \mathrm{mnt}$ & 4480 & 7.7 \\
\hline $11 / \mathrm{e}$ & $2 \mathrm{~mL}$ & 4510 & 6.9 & Aerasi $45 \mathrm{mnt}$ & 4490 & 7.7 \\
\hline $12 / f$ & $2 \mathrm{~mL}$ & 4510 & 6.9 & Aerasi $60 \mathrm{mnt}$ & 4430 & 8.2 \\
\hline
\end{tabular}

Sumber : Pengolaha Data, 2016

Pemberian cuka $2 \mathrm{~mL}$ pada botol 10/d, 11/e, dan 12/f tidak memberikan perubahan $\mathrm{pH}$ dari sebelumnya. Hal itu dikarenakan limbah tersimpan semalam dan telah terjadi dikomposisi sehingga kualitas cuka belum mencukupi untuk merubah kualitas total limbah sehingga keberadaannya dapat diabaikan, dan jika dibaui ke enam botol tersebut tercium sangat bau busuk.

Tujuan dari percobaan ini adalah percobaan diharapkan mampu menunjukkan pengaruh ozon terhadap produksi bau awal limbah cair. Hasil percobaan disajikan pada Gambar 4 dan Tabel 3.

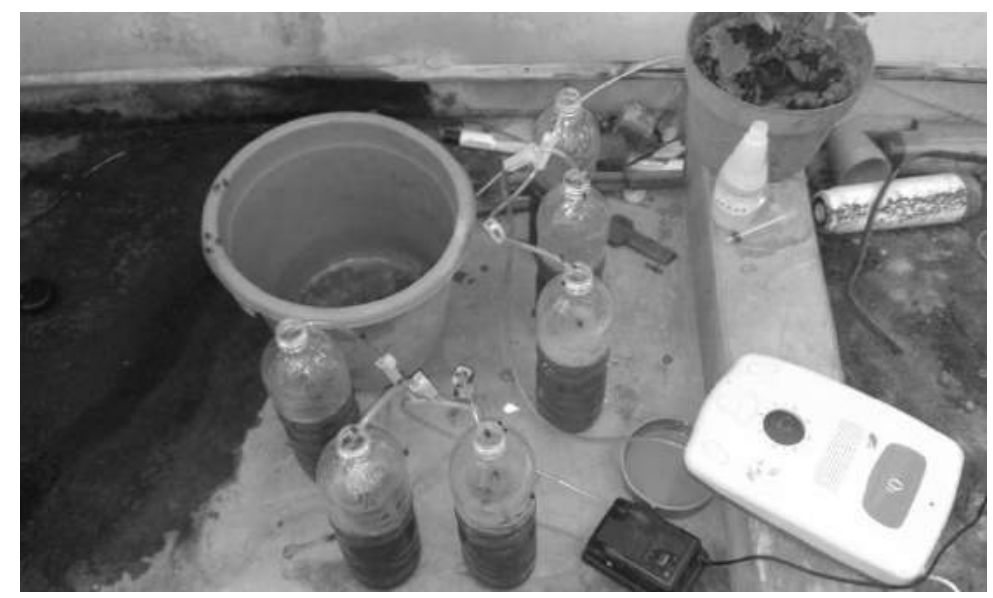

Gambar 4.

Foto Percobaan Tahap Kedua dengan Waktu 30, 45, 60 Menit Sumber : Pengamatan Lapangan, 2016

Gambar 4 menunjukkan bahwa ke enam botol terlihat banyak dihinggapi lalat hijau. Kondisi keenam botol pada percobaan tahap kedua berbau busuk. Menurut Dian (2008), produksi bau busuk akan disukai oleh lalat hijau. Sedangkan, jumlah lalat hijau setiap waktu pada keenam botol dengan variasi aerasi dan ozonisasi ditampilkan dalam tabel 3. 
Tabel 3.

Perhitungan Lalat Hijau Pada Percobaan Tahap Kedua

\begin{tabular}{|c|c|c|c|c|c|c|c|c|c|}
\hline \multirow{2}{*}{$\begin{array}{l}\text { Waktu } \\
\text { kontak }\end{array}$} & \multicolumn{8}{|c|}{ Kehadiran lalat hijau ( ekor) } & \multirow{2}{*}{ Keterangan } \\
\hline & A & $\mathrm{D}$ & $\mathrm{B}$ & $\mathrm{E}$ & $\mathrm{C}$ & $\mathrm{F}$ & Luar & Populasi & \\
\hline 16.36 & 0 & 0 & 0 & 0 & 0 & 7 & 0 & 7 & Botol A,B,C,D,E,DAN F berisi limbah cair 1 liter \\
\hline 16.47 & 0 & 0 & 1 & 2 & 2 & 12 & 0 & 17 & A Kontak ozon 30 menit,start mnt 30 finish mnt 60 \\
\hline 16.53 & 1 & 0 & 1 & 4 & 2 & 9 & 0 & 17 & B Kontak ozon 45 menit, start mnt 15 finish mnt 60 \\
\hline 16.55 & 0 & 0 & 2 & 4 & 2 & 8 & 2 & 18 & C Kontak ozon 60 menit, start mnt 0 finish mnt 60 \\
\hline 17.02 & 1 & 0 & 3 & 6 & 0 & 1 & 7 & 18 & D Kontak aerasi 30, start mnt 30 finish mnt 60 \\
\hline 17.08 & 2 & 3 & 2 & 0 & 1 & 6 & 4 & 18 & E Kontak aerasi 45, start mnt 15 finish mnt 60 \\
\hline 17.09 & 0 & 1 & 4 & 4 & 4 & 6 & 0 & 19 & F Kontak aerasi 60 , start mnt 0 finish mnt 60 \\
\hline 17.10 & 0 & 5 & 4 & 5 & 4 & 11 & 0 & 29 & Luar : Lalat di luar botol ( data olahan ) \\
\hline 17.11 & 2 & 2 & 6 & 3 & 3 & 11 & 14 & 41 & Populasi : Lalat tercatat dan di luar botol ( data \\
\hline 17.13 & 0 & 2 & 0 & 10 & 0 & 1 & 12 & 25 & Olahan ) \\
\hline 17.14 & 1 & 4 & 3 & 8 & 2 & 4 & 4 & 26 & \\
\hline 17.16 & 0 & 1 & 3 & 9 & 3 & 4 & 0 & 20 & \\
\hline 17.17 & 0 & 0 & 7 & 4 & 0 & 3 & 0 & 14 & \\
\hline
\end{tabular}

Sumber : Pengolaha Data, 2016

Hasil pengolahan sampel dengan menggunakan ozon dan aerasi ini untuk melihat reaksi lalat hijau terhadap bau sampel limbah hasil pengolahan. Sampel limbah akhir hasil pengolahan ditampilkan pada Gambar 5.

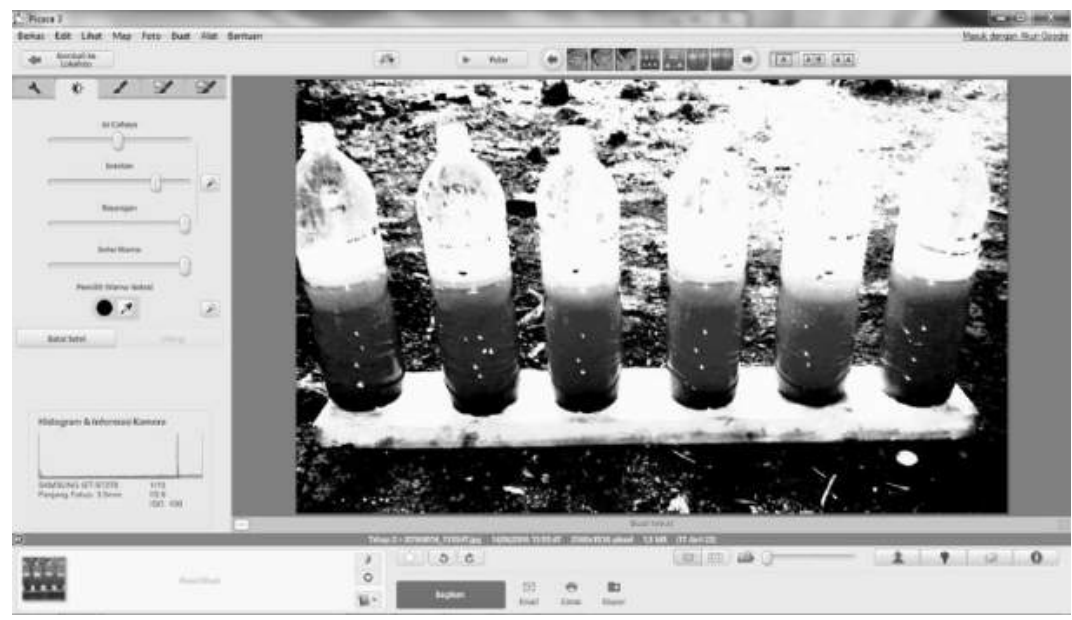

Gambar 5.

Foto Olahan Hasil Percobaan Tahap Kedua

Sumber : Pengamatan Lapangan, 2016 
Hasil percobaan tahap kedua menunjukkan tingkat kecerahan mengalami peningktan. Urutan berdasarkan kecerahan yaitu pertama botol 11/e (aerasi 45 menit; TDS 4.490 $\mathrm{mg} / \mathrm{L} ; \mathrm{pH} 7,7$ ), kedua botol 10/d (aerasi 30 menit; TDS $4.480 \mathrm{mg} / \mathrm{L} ; \mathrm{pH} \mathrm{7,7)}$, ketiga botol 9/c (Ozonosasi 60 menit; TDS 4.400; pH 8,3), keempat botol 8/b (ozonisasi 45 menit; TDS $4.440 \mathrm{mg} / \mathrm{L}$; $\mathrm{pH} 7,9$ ), kelima botol 7/a (ozonisasi 30 menit; TDS $4.510 \mathrm{mg} / \mathrm{L} ; \mathrm{pH} 7,5)$, dan keenam botol 12/f (aerasi 60 menit, TDS $4.430 \mathrm{mg} / \mathrm{L} ; \mathrm{pH} \mathrm{8,2)}$. Pengolahan bau dengan menggunakan cuka, aerasi dan ozon belum mampu menghasilkan pengolahan yang baik. Hasil terbaik yang diperoleh dari percobaan berupa kecerahan warna didapatkan dengan aerasi.

\section{Korelasi Kehadiran Lalat}

Tabel 3 yang menyajikan data kehadiran lalat hijau kemudian diuji dengan menggunakan korelasi statistik. Hal ini dilakukan untuk melihat hubungan keberadaan lalat hijau dengan produksi bau keenam botol yang memiliki perbedaan waktu perlakuan. Hasil uji statistik disajikan pada Tabel 4.

Tabel 4.

Korelasi Lalat Hijau

\begin{tabular}{cccccc}
\hline LALAT BOTOL & A DAN B & A DAN C & A DAN D & A DAN E & A DAN F \\
\hline Pearson Correlation & 0,27 & 0,182 & $-0,269$ & $-0,028$ & 0,096 \\
Sig. (2-tailed) & 0,371 & 0,551 & 0,374 & 0,928 & 0,756 \\
\hline LALAT BOTOL & B DAN C & B DAN D & B DAN E & B DAN F & C DAN D \\
\hline Pearson Correlation & 0,164 & 0,225 & 0,4 & 0,106 & 0,02 \\
Sig. (2-tailed) & 0,593 & 0,46 & 0,176 & 0,73 & 0,947 \\
\hline LALAT BOTOL & C DAN E & C DAN F & D DAN E & D DAN F & E DAN F \\
\hline Pearson Correlation & 0,299 & 0,012 & 0,066 &,$- 556^{*}$ &, $579^{*}$ \\
Sig. (2-tailed) & 0,321 & 0,968 & 0,831 & 0,048 & 0,038 \\
\hline
\end{tabular}

Sumber : Pengolaha Data, 2016

Pemberian aerasi ketiga botol berisi 1 liter limbah cair yang sama, akan menghasilkan karakteristik bau yang sama, akan tetapi yang membedakan adalah kuantitas berdasarkan perbedaan start waktu aerasinya. Demikian juga dengan pemberian ozonisasi ke tiga botol berisi 1 liter limbah cair yang sama, akan menghasilkan karakteristik bau yang sama, akan tetapi yang membedakan adalah kuantitas berdasarkan perbedaan start waktu ozonisasi. Kedatangan lalat hijau menuju bau busuk yang dikeluarkan botol berpengaruh terhadap perbedaan produk bau kedua golongan botol yaitu golongan hasil aerasi dan golongan hasil ozonisasi. Dengan demikian,uji korelasi yang digunakan dengan menggunakan pendekatan kedatangan lalat pada bau yang sama.

Korelasi positif signifikan ditunjukkan oleh lalat hijau e dengan lalat hijau f sebesar 0,579 dengan tingkat keyakinan 0,038. Korelasi negatif signifikan ditunjukkan oleh lalat hijau d dengan lalat hijau $f$ sebesar $-0,556$ tingkat keyakinan 0,048. Artinya lalat hijau e berkorelasi dengan lalat hijau $f$, 
tetapi lalat hijau f tidak berkorelasi dengan lalat hijau d. Lalat e berasal dari f karena aerasi $f$ lebih dahulu, sehingga lalat $\mathrm{f}$ berpindah ke botol e dikarenakan adanya bau baru. Bau baru yang dimaksud adalah bau hasil dari start aerasi mengeluarkan bau baru botol e dan mengundang lalat botol $f$ yang duluan dihinggapi karena start 15 menit dahulu. Lalat hijau d berasal dari lalat botol b,c, dan e akan tetapi tidak signifikan, dan korelasi negatif botol d dengan botol a karena waktu reaksinya bersamaan.

Lalat hijau botol a berkorelasi negatif dengan botol d dan e, akan tetapi berkorelasi positif dengan $b$, c, dan $\mathrm{f}$ walaupun tidak signifikan. Artinya jika a dan $\mathrm{c}$ bersamaan reaksinya maka dimungkinkan lalat a berasal dari $\mathrm{b}$ dan $\mathrm{f}$ tetapi tidak signifikan. Hal demikian juga dengan botol b, c, dan d.

\section{KESIMPULAN DAN SARAN}

\section{Kesimpulan}

Kesimpulan dari percobaan penurunan bau menggunakan cuka, aerasi, dan ozon dengan indikator kehadiran lalat sebagai indikator terbentuknya bau dan dianalisis menggunakan hubungan ke tiga perlakuan sebagai berikut :

1. Percobaan pengolahan menggunakanbahan campuran cuka menghasilkan bau segar sehingga dihinggapi hanya oleh lalat rumah.

2. Percobaan pengolahan dengan memvariasi ozonisasi, aerasi, dan perbedaan waktu menghasilkan bau yang disukai lalat hijau

3. Pengundang lalat hijau berasal dari reaksi aerasi, dan perpindahan lalat ke botol lainnya hanya ditunjukkan korelasi positif signifikan dari botol $\mathrm{f}$ ke botol e, yang lainnya korelasi negatif, positif dan tidak signifikan.

4. Pengolahan yang terbanyak dan sering dihinggapi oleh lalat hijau dengan korelasi 0,579 dengan signifikasi dibawah nilai 0,05 yaitu 0,038 pada pengolahan menggunakan aerasi botol f. Artinya pengolahan ozonisasi kurang diminati oleh lalat hijau.

5. Pengolahan bau (cuka, aerasi dan ozon) yang dilakukan belum mampu menghasilkan pengolahan yang baik, dan hasil terbaik yang diperoleh berupa kecerahan warna didapatkan dengan aerasi.

\section{Saran}

1. Pengolahan limbah cair industri tepung ikan disarankan mengunakan tambahan unit ozonisasi pada awal pengolahan untuk menetralisir dan atau mengurangi bau busuk bawaan ikan sehingga mampu membantu meringankan beban pengolahan pada IPAL dan tidak meresahkan masyarakat.

2. Diperlukan penelitian lanjutan untuk mereplika penelitian ini, dikarenakan kurangnya bahan baku limbah cair dan analisis laboratorium untuk memperkuat argumentasi penurunan bau.

\section{DAFTAR PUSTAKA}

Enjarlis, S. Bismo, Slametdan Roekmijati. $2006 . \quad$ Studi Pendahuluan Ozonasi (Katalitik dan Non Katalitik) Limbah Cair Karbofuran.JurnalReaktor, Vol $10.2: 88-95$.

Isyuniarto dan Purwadi, A. 2006.Kajian Penggunaan Oksidan Ozon Pada Pengolahan Limbah Cair Industri Udang.Ganendra Majalah Iptek Nuklir, Vol 9 No 1 : 19-24. 
Isyuniarto, W.Usada, dan P. Agus. 2007. Degradasi Limbah Cair Industri Kertas Menggunakan Oksidan Ozon dan Kapur.Prosiding PPIPDIPTN. Yogyakarta : Pustek Akselerator dan Proses BahanBATAN.

Suyono dan S. Mardhotillah. 2012. Pengaruh Aroma Umpan dan Warna Kertas Perangkap Terhadap Jumlah Lalat Yang Terperangkap. Jurnal Litbang UMS, Vol $2.2: 30-36$.

Mayasari, D. 2008. Hubungan Panjang Larva Lalat dengan Lama Waktu Kematian Tikus Wistar Yang Didislokasi Tulang Leher Di Semarang. Skripsi. Fakultas
Kedokteran. Semarang : Universitas Diponegoro.

Sari N.N., M.R. Sururi dan K. Pharmawati. 2013.Efek Perlakuan PH Pada Ozonisasi. Jurnal Reka Lingkungan, Vol 1 (1) : 1-12.

\section{BIODATA PENULIS}

Hermain Teguh Prayitno, lahir 11 April 1970 di kota Rembang Jawa Tengah. Magister Ilmu Lingkungan dari Universitas Diponegoro (UNDIP) Semarang tahun 2008. Saat ini bekerja sebagai peneliti pertama di Kantor Penelitian dan Pengembangan Kabupaten Pati. 